\title{
On the Treatment of Muscle Atrophy with Very High Frequency Impulses
}

\author{
By \\ Yoshihiko Umehara \\ (梅 原 芳 彦) \\ From the Department of Internal Medicine, Sendai National \\ Hospital, Sendai. Director: Dr. T. Kat o, Professor \\ Emeritus of Tohoku University \\ (Received for publication, October 13, 1955)
}

It is of a high clinical importance to find the best means of delaying or lessening the onset of muscle atrophy following central or peripheral motor paralysis. Various physical and chemical methods aimed for this purpose have been tried to date, with more or less success. Langley and Kato ${ }^{1 \prime}$ performed the experiment of applying electric stimulation by means of condenser shocks to the gastrocnemius muscle group in one of the legs of rabbits with their tibial nerves on both sides severed, and found that the muscles on the side thus shock-treated were apparently better defended from atrophy than those on the other side. The rhythmic extensions of the paralyzed muscles have also been accepted as efficacious, though in a slight degree, while massage alone of the muscle was not nearly effective for the purpose. Since d'Arsonval first proved the harmless pyrogenic effect of very high frequency, the so-called d'Arsonval's short waves came into application in clinical practice. Later, Schliephake ${ }^{2}$ ) succeeded him by confirming the effective biological action of very high frequency (V.H.F.); G. Takahashi, Hashimoto and T. Takahashi ${ }^{31}$ found extension of muscles, which were exposed to such waves. In consideration of those findings, the author has undertaken the present experiment to observe the therapeutic effect of the very high frequency impulses upon the atrophic process of paralyzed muscles, using a new apparatus which was recently devised by Dr. M. Kobayashi and Dr. T. Kato.

\section{EXPERIMENTAL}

\section{Method}

10 rabbits of about $2 \mathrm{~kg}$. each were employed. The sciatic nerves were severed on both sides, and on from the 3rd to 6th day after operation, the tibial muscles on one side began to be stimulated by placing 
a pair of pole plates $\left(6 \times 6 \mathrm{~cm}^{2}\right)$ thereon of very high frequency impulse apparatus (5-IR-1001) devised by Dr. M. Kobayashi and Dr. T. Kato (1947) and constructed by Nippon Electric Co. Laboratory with the following standard: Input of $100 \mathrm{~V}$ A.C. and $600 \mathrm{~W}$, peak pulse power of ca. $1 \mathrm{KW}$, wave length of $5 \mathrm{~m}$, pulse repetition frequency of 1 cycle $/ \mathrm{sec}$. and ratio pulse duration/pulse repetition period of ca. $\frac{2}{100}$. The stimulation was applied for about $10 \mathrm{~min}$. every day, down to from $3 \mathrm{rd}$ to $62 \mathrm{nd}$ day thereafter. Then, the gastrocnemius muscle groups on both sides were extracted from their proximal tendons down to the level of their insertion of the Achilles tendon and weighed in order to compare the progress of muscle atrophy on both sides, and also a part of the specimens were cut into tissue preparations, to examine their histological changes in comparison.

\section{Results AND Discussion}

The results are shown in Table I. The gastrocnemius muscle groups

TABLE I

Comparison of the Muscle Weights of Treated and Non-treated Sides

Figures of the treated side in gothic type

\begin{tabular}{|c|c|c|c|c|c|c|c|c|c|}
\hline $\begin{array}{l}\text { No. } \\
\text { of } \\
\text { Exp. }\end{array}$ & Sex & $\begin{array}{l}\text { Body } \\
\text { weight } \\
\text { (kg.) }\end{array}$ & $\begin{array}{l}\text { Ditto } \\
\text { at } \\
\text { death } \\
\text { (kg.) }\end{array}$ & $\begin{array}{l}\text { Percentage } \\
\text { loss of } \\
\text { weight }\end{array}$ & $\begin{array}{l}\text { Days after } \\
\text { nerve } \\
\text { section until } \\
\text { impulse } \\
\text { applied }\end{array}$ & 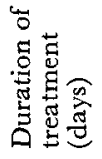 & \multicolumn{2}{|c|}{$\begin{array}{l}\text { Weight of } \\
\text { gastrocne- } \\
\text { mius group } \\
\text { (g.) }\end{array}$} & $\begin{array}{c}\text { Percentage } \\
\text { gain on } \\
\text { stimulated } \\
\text { side }\end{array}$ \\
\hline 1 & 우 & 2.0 & 1.6 & -20.0 & 2 & 3 & 5.65 & 6.26 & +10.8 \\
\hline 2 & $\hat{\delta}$ & 1.9 & 1.7 & -10.5 & 5 & 12 & 3.52 & 4.00 & +13.6 \\
\hline 3 & 今 & 2.8 & 2.8 & \pm 0 & 5 & 11 & 6.26 & 7.28 & +16.3 \\
\hline 4 & 우 & 2.8 & 2.3 & -17.9 & 4 & 58 & 2.23 & 2.82 & +17.5 \\
\hline 5 & 今 & 2.0 & 1.8 & -10.0 & 5 & 30 & 3.60 & 3.15 & +14.3 \\
\hline 6 & ô & 2.2 & 2.0 & -9.1 & 14 & 22 & 3.68 & 3.46 & +6.4 \\
\hline 7 & 우 & 2.2 & 2.1 & -4.5 & 5 & 32 & 4.15 & 3.52 & +17.9 \\
\hline 8 & 우 & 2.2 & 2.0 & -9.1 & 5 & 30 & 3.82 & $\mathbf{4 . 2 7}$ & +11.8 \\
\hline 9 & $\delta$ & 2.2 & 1.8 & -18.2 & 5 & 62 & 2.00 & 2.38 & +19.0 \\
\hline 10 & 今 & 2.0 & 1.8 & -10.0 & 5 & 21 & 3.66 & 3.55 & +9.3 \\
\hline \multicolumn{2}{|c|}{ Average } & 2.2 & 2.0 & -10.9 & 6 & 28 & 3.72 & 4.21 & +13.2 \\
\hline \multicolumn{2}{|c|}{$\begin{array}{l}\text { Standard } \\
\text { deviation }\end{array}$} & & & \pm 4.7 & & & \pm 1.33 & $=1.37$ & \pm 4.1 \\
\hline \multicolumn{2}{|c|}{ Maximum } & 2.8 & 2.8 & \pm 0 & 14 & 62 & 6.26 & 7.28 & +19.0 \\
\hline \multicolumn{2}{|c|}{ Minimum } & 1.9 & 1.6 & -20.0 & 2 & 3 & 2.00 & 2.38 & +6.4 \\
\hline
\end{tabular}


of the rabbits were treated with the impulse stimulation apparatus on one side for 3 to 62 days, for 28 days on an average, after the section of the sciatic nerves on both sides. All the rabbits, excepting only one case (No. 3) lost body weight, the mean percentage of loss in weight amounting to $10.9 \pm 4.7$. The weight of the muscle group with severed nerve and not stimulated by the impulse was $6.26 \mathrm{~g}$. at the maximum, $2.00 \mathrm{~g}$. at the minimum and $3.72 \pm 1.33 \mathrm{~g}$. in the mean, while that of the muscle group on the stimulated side amounted to $7.28 \mathrm{~g}$. at the maximum, $2.38 \mathrm{~g}$. at the minimum and $4.21 \pm 1.37 \mathrm{~g}$. on an average, showing an excess over that on the unstimulated side of $19 \%$ at the maximum, of $6.4 \%$ at the minimum and of $13.2 \pm 4.1 \%$ on an average.

According to Langley and Kato, ${ }^{11}$ the gastrocnemius muscle groups, when cut off from their nervous control, will begin to decrease in weight on the 3rd day after the neurectomy, losing weight rapidly thereafter, to become reduced by $30 \%$ at the end of the 2 nd week. Thence, the speed of decrease slackens somewhat, but yet, at the end of the 5th week, the loss in weight is said to reach $50 \%$ of the orginal weight. In No. 1 of the present experiment, the stimulation was applied for 3 days starting on the 3 rd day after the nerve cutting, and the weight of the muscle groups on the 4 th day thereafter was $6.26 \mathrm{~g}$. on the stimulated side and in excess of $10.8 \%$ over that of the muscle group on the untreated side, $5.65 \mathrm{~g}$., suggesting that the impulse treatment was effective in suppressing the atrophy of the muscles in some extent. In No. 2, the application of impulses was begun on the 6th day and continued for 12 days. On the 13 th day, the stimulated muscle group weighed $4.00 \mathrm{~g}$., showing an increment of $13.6 \%$, in comparison with the group on the other side which had the weight of $3.52 \mathrm{~g}$. In No. 6, the stimulation was begun on the 15th days, when the muscle atrophy had progressed to a considerable extent, and continued for 22 days. The muscles weighed $3.68 \mathrm{~g}$., while the weight of the muscles on the other side left untreated for 36 days after the nerve cutting was $3.46 \mathrm{~g}$., the difference amounting only to $6.4 \%$. Thus, when the muscle atrophy has considerably progressed by the lapse of 2 weeks, as in this case, the impulse stimulation is little effective in preventing further atrophy. In the remaining 7 cases, the stimulation was begun on the 6th day after the nerve cutting operation, that is, in the early stage of muscle atrophy, and continued for 11 to 62 days. The comparison with the control side muscles thus left untreated for 16 to 67 days after the denervation showed excess in the weight of the stimulated muscles with the difference of 9.3 to $19 \%$, but in all cases the muscle atrophy was observed on both sides progressing in parallel, while the fibrillations, which occur continuously in the atrophying muscle as rapid rhythmic contraction of the muscle fibres, was mild on the treated side. 
Histological examination of the atrophic muscle showed that in the specimens stimulated with impulse the dilatation of the capillaries was much more marked and degenerative changes of muscle fibres and fibre celles were somewhat less advanced than in the untreated groups.

Thus, it may be concluded that V.H.F. administered in impulse act in suppressing atrophy of muscles, the impulses giving rise to contraction of the muscles, which, under the action of the micro-waves, more or less extend out, the capillaries dilate and the blood circulation is expedited, thus contributing to protection of the muscles from atrophy. The treatment, however, must be begun within 2 weeks after the blocking of the nervous control and should be continued in daily administration. As for the effective period of continued treatment, the author's experiments seem to indicate that the atrophy preventing effect is notable for the first two months, but the muscle atrophy does sooner or later occur even in the treated muscles, as in untreated muscles, and it is probably impossible to prevent onset of fibrillation of muscles to some extent.

\section{Summary}

The sciatic nerves of 10 rabbits were severed on both sides and very high frequency impulses were administered to their gastrocnemius muscle groups unilaterally. In 3 to 62 days after the beginning of the stimuation, the muscles groups were cut out at the insertion of the tendons on both sides and weighed, for estimating the degree of muscle atrophy in comparison. The results obtained were as follows :

1. The weight of the gastrocnemius muscles on the treated side in comparison with that of the muscles on the other side was always larger and apparently showed that such a treatment was effective in controling muscle atrophy.

2. The impulse treatment should be begun in a short period after the cutting off of the nervous control and should be continued in daily administration more than two months.

\section{References}

1) Langley \& Kato, J. Physiol., 1915, 49, 432.

2) Schliephake, Dtsch. med. Wschr., 1932, 1235.

3) G. Takahashi, Hashimoto \& T. Takahashi, Tohoku Igaku Zasshi, (Jap.), 1942. 31, 65, 